\title{
Resenha \\ Governabilidade e pobreza no Brasil
}

Valladares, Licia \& Prates Collho, Magda (org.).

Governabilidade e pobreza no Brasil.

Rio de Janeiro: Civilização Brasileira, 1995.

Governabilidade e pobreza no Brasil é a publicação editada pela Civilização Brasileira, da coletânea de trabalhos apresentados no seminário sobre o tema, promovido pelo IUPERJ (Instituto Universitário de Pesquisas do Rio de Janeiro).

Esta coletânea organizada por Licia Valladares e Magda Prates Coelho traz uma reflexão sobre temas como a reforma do Estado e a restauração da autoridade, as relações entre Estado e sociedade civil, as relações entre democracia e desigualdade e a crescente demanda por um modelo de desenvolvimento em que prevaleçam os princípios da justiça social e da eqüidade e que garanta o fortalecimento das instituições democráticas. Elisa P. Reis, Lino Ferreira Netto, Luiz César de Queiroz Ribeiro, Marcus André B. C. de Melo, Paul Singer, Regina Sílvia Pacheco, Sílvio Caccia Bava, Sônia Rocha e Sulamis Dain mostram como associar governabilidade e democracia a uma politica econômica capaz de garantir a retomada do desenvolvimento com aumento da inclusão social.

O livro foi organizado em três partes: a primeira reúne os textos sobre "Governabilidade, Sociedade Civil e Reforma do Estado"; a segunda sobre "Governabilidade Urbana: Governos Locais e Participação"; e a terceira parte sobre "Governabilidade, Desigualdade e Políticas para a Pobreza".

Na primeira parte, os artigos de Marcus André B. C. de Melo, Elisa P. Reis e Sulamis Dain trazem uma discussão teórica e contextual das noções de governabilidade, governança e sociedade civil. Estudam os entraves à governabilidade no Brasil, destacando os principais pontos da

Resenha claborada por José Luiz Pagnussat, Técnico da Diretoria de Treinamento e Desenvolvimento da ENAP 
economia e da sociedade que precisam ser superados para se viabilizar a reforma do Estado e associar governabilidade e democracia a uma politica econômica capaz de garantir a consolidação do desenvolvimento com maior participação social.

$\Lambda$ questão da governabilidade e governança assumiu destaque no debate político recente. Surge nos países capitalistas na década de 70 como instrumento analítico do diagnóstico conservador frente a um quadro de estagflação associada aos excessos do Welfare State e à crise de autoridade (MELo, p. 24). Ganha destaque no Brasil a partir do final do governo Sarney e domina a agenda politica nos anos recentes com um conjunto de argumentos controversos que vêm pautando o projeto de reformas do governo. Os autores aprofundam a análise crítica destes argumentos e apontam alguns equívocos.

Elisa Reis analisa a evolução da questão da governabilidade; surgiu como instrumento do diagnóstico direitista e se transformou em escudo ético-moral para a direita e esquerda. Destaca que governabilidade pressupõe capacidade de desempenho em uma arena pública que seja relevante para os diferentes setores, grupos e interesses.

Para MELo (p. 48), o problema da governabilidade se circunscreve, num plano mais amplo, na questão das virtudes da democracia e de sua capacidade resolutiva e, num plano mais imediato, ela diz respeito aos imperativos do ajuste econômico e, principalmente, da produção de bens públicos e da redução da desigualdade e eliminação da pobreza numa sociedade estruturalmente heterogênea.

A coletânea de artigos das segunda e terceira partes do livro aprofunda a análise das realidades municipal e metropolitana, a partir da crise dos anos 80 . Revela avanços e desafios na gestão democrática das cidades.

Lino Ferreira Netto analisa as possibilidades e limitações da atuação do município no combate à pobreza, destacando a ampliação de competências e responsabilidades dos municípios com a descentralização.

Luiz César de Queiroz Ribeiro questiona a (in)governabilidade das cidades e observa que uma análise mais minuciosa da política social e das ações dos governos municipais na área social não autoriza a falar $\mathrm{em}$ crise de governabilidade. Revela que a reforma institucional-jurídica dos municipios implantou as condições de um novo modelo de planejamento e gestão da cidade, democrática, universalista e redistributiva dos beneficios e custos da urbanização.

Silvio Caccia Bava em seu artigo "Dilemas da Gestão Municipal Democrática" destaca três questões fundamentais: a construção de um projeto de desenvolvimento, a construção do espaço público e o exercício da governabilidade enquanto capacidade essencialmente política de negociação. Conclui que o exercicio da governabilidade por parte dos governos 
municipais democráticos reside, fundamentalmente, na sua capacidade de negociação política. De conquistar a adesão dos múltiplos atores sociais, presentes no cenário municipal, a um projeto de desenvolvimento que atenda às necessidades da maioria.

Uma experiência de gestão municipal democrática é apresentada por Paul Singer que analisa o governo Luiza Erundina na prefeitura de São Paulo - 1989/92 - destacando a parceria entre o poder público e as organizações populares no combate à pobreza.

Regina Silvia Pacheco destaca que as metrópoles brasileiras constituem um dos grandes desafios à governabilidade do pais e denuncia um vácuo político-administrativo na escala supralocal, com o fracasso do modelo tecnocrático e a inexistência de novos modelos alternativos para a gestão metropolitana. A Constituição de 1988 não contemplou esta matéria, transferindo tal competência para os Estados.

Sônia Rocha apresenta um retrato da pobreza no Brasil. Mostra um quadro pouco alentador e conclui que a questão da pobreza, junto às questões de estabilização e retomada do desenvolvimento econômico, formam o cerne do desafio da sociedade brasileira quanto à governabilidade e à sobrevivência democrática.

Em sintese, os cientistas sociais reunidos neste livro oferecem uma reflexão substantiva e alguns parâmetros às gestões municipais comprometidas com o ideário da gestão democrática e dos principios da justiça social e da eqüidade. 
A Revista do Serviço Público é uma publicação da Escola Nacional de Administração Pública - ENAP, voltada para a divulgação e debate de temas relacionados ao Estado, à Administração Pública e à Gestão Governamental. Procurando o aprimoramento permanente da revista, tanto no seu conteúdo quanto na apresentação gráfica, pedimos aos nossos colaboradores a observação das normas abaixo descritas.

\section{Normas para os colaboradores}

1. Os artigos, sempre inéditos no Brasil, deven conter em torno de 25 laudas de 20 linhas de 70 toques.

2. Os originais devem ser encaminhados ao Editor em disquete, em programa de uso universal, com uma cópia impressa. Usar apenas as formataçòes-padrão.

3. Cada artigo deve vir acompanhado de um resumo analítico $\mathrm{cm}$ português, cspanhol e inglês, de cerca de 150 palavras, que permita uma visão global e antecipada do assunto tratado.

4. Na primeira página do artigo, deve constar informação sobre formação $\mathrm{c}$ vinculação institucional do autor ( $\mathrm{cm}$ até duas linhas).

5. Notas, referências e bibliografia devem vir ao final do artigo, e não ao pé da página. Notas c referências, sendo o caso, devem vir devidamente numeradas.

6. Além de artigos, a Revista receberá comunicą̧ões, notas informativas, notícias e relatórios conclusivos de pesquisas em desenvolvimento, com até 15 laudas. Resenhas de livros, $\mathrm{cm}$ torno de 4 laudas, devem conter uma apresentação sucinta da obra e cventuais comentários que situcm o leitor na discussào.

7. Os trabalhos que se adequarem à linha temática da Revista serão apreciados pelo Conselho Editorial, que decidirá sobre a publicação com base em pareceres de consultores ad hoc.

8. Os originais enviados à Revista do Serviço Público não serão devolvidos. A Revista compromete-se a informar os autores sobre a publicação ou não de seus trabalhos.

\section{Convite a Resenliadores}

A Revista do Serviço Priblico convida todos os interessados em remeter resenhas de trabalhos publicados no Brasil e no exterior sobre Estado, Administração Pública e Gestão Governamental.

As resenhas devem ser originais e não exceder a 5 laudas datilografadas em espaço duplo com 20 linhas de 70 toques, e devem apresentar de modo sucinto a obra, com comentários que situem o leitor na discussão apresentada.

As resenhas deven ser enviadas em português, sem notas de rodapé, contendo o título completo e subtítulo do livro, nome completo do autor, local de publicação, editora $\mathrm{c}$ ano de publicação, bem como uma breve informação sobre a formação $\mathrm{e}$ vinculação institucional do resenhador (em atć duas linhas), acompanhadas do respectivo disquete.

\section{Nota aos Editores}

Pedimos encaminhar à Revisıa do Serviço Prublico exemplares de livros publicados, a fim de serem resenhados. Os resenhadores interessados receberão cópias dos livros enviados. 